\title{
ANTONIM DALAM AL QUR'AN PERSPEKTIF ALI AL-KHULI (KAJIAN SEMANTIK DALAM SURAT LUQMAN)
}

\author{
Miftahul Mufid \\ IAI Sunan Giri Bojonegoro \\ Email : miftahul.mufid@gmail.com
}

\begin{abstract}
Abstrak :
“Al-Qur'an adalah kalamullah yang di turunkan kepada nabi Muhammad. Dan AlQur'an di turunkan kepada nabi Muhammad menggunakan bahasa Arab. Oleh sebab itu untuk memahami kitab suci ini perlu mengetahui kaidah-kaidah ilmu Bahasa Arab, seperti Nahwu, Sharf, dan Dilalah. Ilmu Dilalah menjadi penting untuk di pelajari untuk mengetahui makna di dalam Al-Qur'an. Salah satu pembahasan dalam ilmu Dilalah adalah al-tadhad (antonim). Ali al-Khuli merupakan sosok yang paling berpengaruh dalam mengembangkan ilmu Dilalah modern. Oleh sebab itu dalam artikel ini akan membahas tentang bagaimana antonim di dalam surat Luqman. Dan teori yang di gunakan dalam mencari bentuk antonim dalam Surat Luqman menggunakan teori Ali al-Khuli dan menurtnya antonim dalam bahasa Arab terbagi menjadi sembilan jenis. Akan tetapi dalam Surat Luqman hanya terdapat enam jenis saja. antara lain: Biner, bagian, cycling, conversense, graded, dan affinity."
\end{abstract}

Kata kunci : antonim, Dilalah, Semantik, Al-Qur'an, Luqman.

\section{A. Pendahuluan}

Al-Qur'an adalah kalamullah (firman Allah) yang di turunkan kepada nabi Muhammad. ${ }^{1}$ Kitab suci ini turun kepada nabi Muhammad selama 23 tahun. Menurut Quraishihab AlQur'an adalah kalamullah yang bersifat mukjizat yang di turunkan kepada nabi Muhammad melalui perantara Jibril dengan lafal dan maknanya dari Allah, yang di nukilkan secara mutawatir. ${ }^{2}$ Sedangkan bagi orang yang membacanya akan bernilai ibadah. Oleh sebab itu

\footnotetext{
${ }^{1}$ Muhammad Iqbal A. Gazali, fadhlu qira'at al-Qur'an. (Mamlakah Saudi: IslamHouse. 2010). 23

${ }^{2}$ M. Quraish Shihab, et. all., Sejarah dan Ulum Al-Qureean, (Jakarta: Pusataka Firdaus, 2008), hal. 13.
} 
menjadi ke wajiban bagi seorang muslim untuk selalu berinteraksi dengan Al-Qur'an baik dengan cara membaca lebih-lebih jika mau mempelajari dan memahaminya.

Kitab yang di turunkan kepada nabi Muhammad ini berisi tentang petunjuk bagi orang yang beriman. Allah berfirman dalam al-Qur'an surat al-A'raf :2

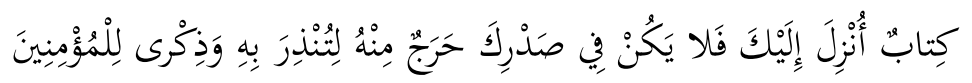

Artinya : "ini adalah sebuah Kitab yang diturunkan kepadamu, Maka janganlah ada kesempitan di dalam dadamu karenanya, supaya kamu memberi peringatan dengan Kitab itu (kepada orang kafir), dan menjadi pelajaran bagi orang-orang yang beriman.”

Dari ayat ini menunujukkan bahwa al-Qur'an merupakan pegangan hidup yang menjadi petunjuk bagi orang yang beriman agar tidak tersesat ke jalan yang salah. Akan tetapi terjadi masalah disini. Pertama al-Qur'an turun dengan bahasa yang berbeda dengan bahasa yang kita gunakan karena al-Qur'an turun dengan Bahasa Arab. Kedua, untuk memahami al-Qur'an di butuhkan kajian ilmu yang kompleks mulai dari ilmu Nahwu, Sharaf, Mantiq, Balaghah, dna Dilalah.

Sebuah petunjuk akan menjadi sia-sia bagi seseorang jika tidak bisa membaca petunjuk yang di berikan. Semisal ketika seseorang ingin pergi ke suatu tempat akan tetapi dia tidak bisa membaca arah petunjuk yang sudah ada sudah bisa di pastikan dia akan tersesat. Hal tersebut merupakan ilustrasi yang sederhana bahwa sebuah petunjuk tidak akan berarti apaapa jika seseorang tidak mampu membaca petunjuk atau ketika bisa membaca petunjuk tersebut akan tetapi tidak mau mengikuti arah petunjuk tersebut. Oleh sebab itu wajib bagi seorang muslim yang ingin mempelajari al-Qur'an tersebut untuk belajar Bahasa Arab.

Salah satu ilmu yang penting untuk memahami bahasa Arab selain nahwu, Sharf adalah ilmu Dalalah / Semantik. Karena dengan mempelajari ilmu semantik berarti kita akan mempelajari tentang makna. ${ }^{3}$ Kajian semantik sangat di perlukan untuk menganilisis makna yang terkandung dalam ayat Al-Qur'an. Seperti kata قائم زيد زيد jika di terjemahkan ke dalam bahasa Indonesia artinya sama yakni 'Zaid berdiri'. Akan tetapi secara makna mempunyai perbedaan. Jika 'Zaidun Qiumun' yang menjadi titik adalah Zaid benar berdiri,

\footnotetext{
${ }^{3}$ Chaer, Abdul. Penggunaan Imbuhan Bahasa Indonesia. (Flores: Nusa Indah. 1989). 60
} 
akan tetapi kata 'Qama Zaidun' yang menjadi titik tekannya ada pada waktu Zaid berdiri, dan ini menunjukkan bahwa Zaid telah berdiri.

Dalam ilmu semantik terdapat pembahasan tentang Antonim atau sering kita sebut lawan kata dalam bahasa Arab di sebut at-tadhad. Dan ternyata dalam Al-Qur'an juga terdapat kata yang berantonim dalam satu ayat. Semisal di dalam Al-Qur'an Surat Luqman sering terulis kata ارض ارماوات bumi dangit dan tidak dalam keadaan terpisah antar ayat akan tetapi selalu tertulis dalam satu ayat. Oleh sebab itu dalam artikel akan di bahas lebih dalam tentang antonim di dalam surat Luqman.

\section{B. Pengertian Antonim}

Kata 'antonim' berasal dari bahasa yunani kuno yakni dari kata, onoma-nama, dan anti = melawan. ${ }^{4}$ menurut kridalaksan antonim adalah laksem yang berpasangan secara antonim. ${ }^{5}$ Selain itu Chaer juga memberikan definisi antonim sebagai ungkapan (biasanya berupa kata, tetapi dapat pula dalam bentuk frase atau kalimat) yang maknanya dianggap kebalikan dari makna ungkapan lain. ${ }^{6}$

Dalam bahasa Arab kata antonim mempunyai padanan kata al-tadhah. Secara bahasa asal kata al-tadhadh adalah dari kata ضد يضد ضد yang artinya adalah menolak, berlawanan, atau kontradiksi.

\section{Jenis Antonim Perspektif Muhammad Ali Al-Khuli}

Dalam pembagian mengenai jenis-jenis antonim, setiap pakar linguis mempunyai pendapat yang berbeda-beda. Menurut Fromkin dan Rodman dalam Moh. Matsna menyebutkan bahwa terdapat tiga jenis antonim yakni complementary, gradable, dan relation opposite, Sedangkan Moelino menambahkan satu jenis antonim yakni antonim yang berhubungan dengan gerak dan arah. ${ }^{7}$

\footnotetext{
${ }^{4}$ Abdul Chaer, Pengantar semantik bahasa Indonesia (Jakarta : Rineka Cipta, 2002). 88

${ }^{5}$ Harimurti Kridalaksana, Kamus Linguistik. (Jakarta: Gramedia Pustaka Utama, 2001).15

${ }^{6}$ ibid. 88

${ }^{7}$ Mohammad Matsna, Kajian Semantik Arab Klasik Dan Kontemporer, (Jakarta: Kencana, 2016). 33
} 
Lain halnya dengan Saeed dalam Kholison menyebutkan bahwa antonim memiliki jenis, antara lain: Antonim sederhana, antonim bertingkat, antonim kebalikan (reverse), antonim konversi (converse), dan antonim taksonomi (taxonomic sister). ${ }^{8}$ Lain halnya dengan tokoh linguis tanah air Soedjito jika di lihat dari jenisnya maka antonim hanya terbagi menjadi tiga yakni antonim kembar, bertingkat dan kebalikan. ${ }^{9}$

Dari beberapa pendapat tersebut menunjukkan bahwa para pakar linguistik secara garis besar cenderung ingin menyederhanakan jenis antonim. Akan tetapi karena objek kita yang sedang di kaji adalah kitab suci al-Qur'an, yang menggunakan bahasa Arab maka perlu menggunakan perspektif pakar linguis Arab. Dan diantara banyak tokoh linguis arab yang fokus mengkaji semantik salah satunya adalah Muhammad Ali al-Khuli. Menurutnya antonim terbagi menjadi sembilan jenis, antara lain: ${ }^{1}$

1. تضاد حاد / binary antonymy, antonim jenis ini menutup adanya kemungkinan oposisi lain secara mutlak. Seperti contoh kata حيت (midup) dan حيت (mati) diantara keduanya terdapat perbedaan yang mutlak. Contoh lain kata اعزب (bujangan) dan متزوج (menikah) diantara keduanya terdapat pembatas yang mutlak. Oleh karena antonim ini tidak mungkin bertingkat.

2. ع / conversense, antonim jenis ini adalah antonim yang sifatnya saling melengkapi antara satu kata dengan kata yang lain. Seperti kata اشترى (membeli) dan باع (menjual) karena setiap ada orang yang menjual pasti ada orang yang membeli, atau والدة seperti kata (wanita yang sudah beranak), maka pasti ada kata مولود (anak yang

\footnotetext{
${ }^{8}$ Mohammad Kholison, semantik bahasa arab tinjauan historis, teoritik dan aplikatif, (Sidoarjo: Lisan Arabi, 2016). 233

${ }^{9}$ Soedjitno, Kosakata Bahasa Indonesia (Jakarta: Gramedia, 1990). 83

${ }^{1}$ Kholison, semantik ........ . 239-242
} 
dilahirkan), karena akan mustahil jika ada والدة (wanita yang sudah beranak) tanpa ada yang dilahirkan (مولود).

3. تضاد متدرج / graded antonymy, antonim jenis adalah antonim berupa pasangan kata yang saling berposisi akan tetapi masih bergradasi, jenjang, atau tingkatan. Jadi kata antonim jenis ini dapat berupa kata-kata nama santun, ukuran (berat, panjang, dan isi), nama stuan hitungan, penanggalan, atau nama jenjang kepangkatan. Contoh lafadz (سهل) mudah antonimnya adalah (صعب) sulit. Akan tetapi dua kata ini masih memiliki tingkatantingkatan misalnya: سهل جدا (sangat mudah), سهل قليل (agak mudah). Tegas Kholison yang menjadi pembeda dari antonim bertingkat dan biner adalah antonim bertingkat dapat menerima tingkatan sedangkan antonim biner tidak memliki tingkatan, seperti kata حي mati tidak mungkin kata ini menerima gradasi seperti contoh (ميت) (حي) (حي) جد agak mati.

4. تضاد عمودي / vertical antonymy, antonim jenis ini memiliki pasangan kata yang menunjukkan dua arah yang vertikal (menyamping) tidak lurus. Contoh kata شمال utara antonimnya adalah شرق شرب dimur. Karena bisa saja antonimnya شمال dan barat. Karena sifat dari antonim ini hubungannya tidaklah satu arah saja.

5. تضاد امتدادي / extensional antonymy, antonim jenis ini adalah jika pasanga katanya menunjukkan dua arah yang bersifat ekstensional (garis lurus). Seperti kata شمال dan

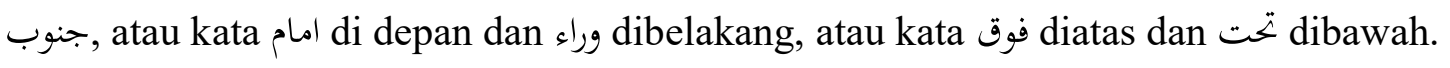

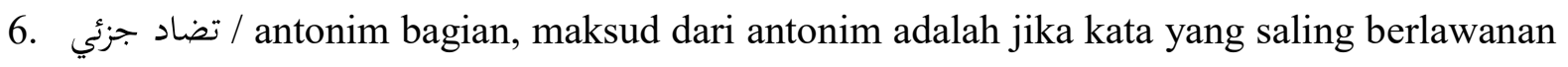
itu merupakan bagian darinya. Seperti contoh kata غلاف sampul. 
Ataupun kata ميارة antonimnya مقود setir. Jadi antara sampul merupakan bagian dari kitab, sedangkan setir merupakan bagian dari mobil. Karena merupakan bagian dari lawan katanya maka antonim ini di beri nama جزئي yang berarti bagian.

7. تضاد دائري / cyclic antonymy, jika antonim sebuah kata memiliki hubungan putaran. Misalnya lawan kata hari senin adalah selasa, ataupun lawan kata musim kemarau adalah musim penghujan. Karena senin dan selasa merupakan perputaran atau kata kemarau dan penghunjan merupakan putaran musim.

8. الرتبي / rank antonymy, sifat kata dari antonim jenis adalah jika antonimnya berenking untuk memahaminya lihat kata berikut: مشير jendral besar, فريق اول jendral, فريق letnan jendral, لواء mayor. Dari beberapa kata di atas menujukkan lawan kata akan masih dalam tataran kepangkatan militer. Jadi kerena masih dalam satu tataran urutan maka antonim jenis ini dinamakan rank antonymy.

9. berantonim merupakan kelompok dari jenis yang sama. Misal kata موز pisang, تفاح apel, برتقال jeruk, dari beberapa kata ini merupakan dari satu kelompok jenis yang sama yakni jenis فاكهة buah-buahan.

\section{Sekilas Tentang Muhammad Ali Al-Khuli}

Muhammad Ali al-Khuli adalah tokoh yang sangat getol dalam menuliskan karya dalam bidang linguistik. Dalam kalangan liguis dia lebih di kenal dengan nama al-Khuli. Dia lahir pada tanggal 23 November tahun 1938 di kota Manufiyah. Dia merupakan sosok pakar linguistik di Mesir. Dalam kesehariannya dia berprofesi sebagai penulis, peneliti, dan penterjemah. Selian itu dia juga bekerja sebagai jurnalis, konsultan dan pemateri baik di radio, media cetak ataupun di lembaga pelatihan baik di dunia arab dan eropa. Tokoh ini juga aktif dalam menerbitkan artikel dan tulisannya seputar kajian bahasa baik di Mesir maupun di luar 
negeri. Karena kemahirannya dalam ilmu linguistik inilah yang menjadikan dia di daulat menjadi anggota kemite penerjemah kementrian kebudayaan di Mesir. Dia memperoleh gelar sarjana BA dalam jurusan sastra Inggris di universitas Kairo. Kepiawaiannya dalam menerjemah bahasa asing inilah yang akhirnya menjadikannya sebagai anggota penterjemah untuk PBB (Perserikatan Bangsa Bangsa). ${ }^{1}$

\section{E. Antonim Dalam Surat Luqman}

Untuk memudahkan dalam mengetahui ayat dalam Surat Luqman yang berisi antonim lihat tabel berikut.

Tabel. 1

\begin{tabular}{|c|c|c|c|}
\hline No. & Ayat & Isi & Jenis \\
\hline 1 & 10 & 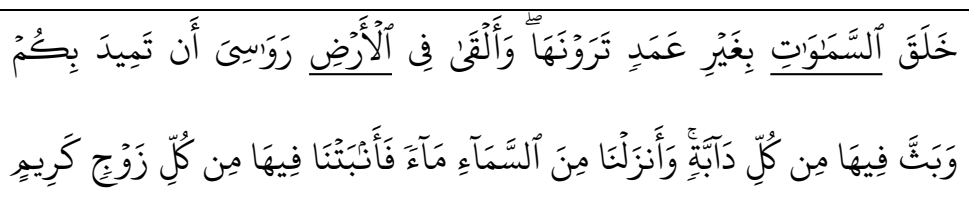 & Binary antonymy \\
\hline 2 & 12 & 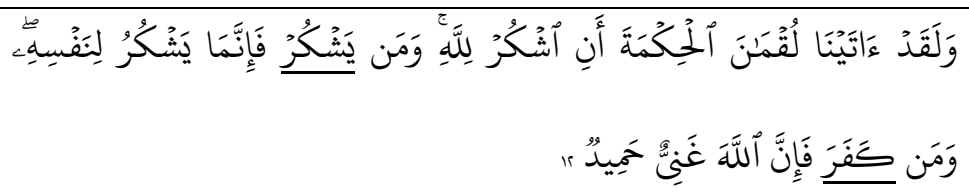 & Binary antonymy \\
\hline 3 & 16 & 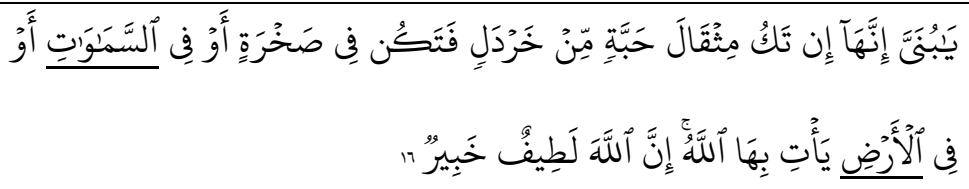 & Binary antonymy \\
\hline 4 & 17 & 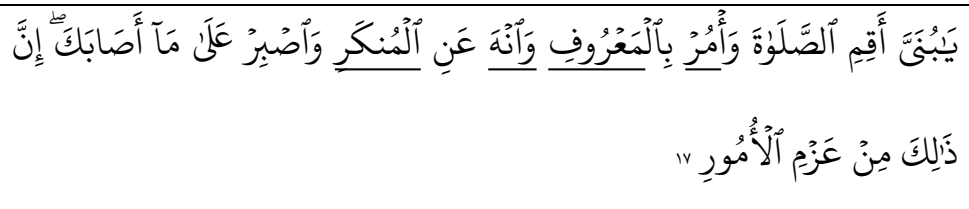 & $\begin{array}{lr}\text { Binary } & \text { antonymy } \\
\text { dan } & \text { graded } \\
\text { antonymy } & \end{array}$ \\
\hline 5 & 20 & 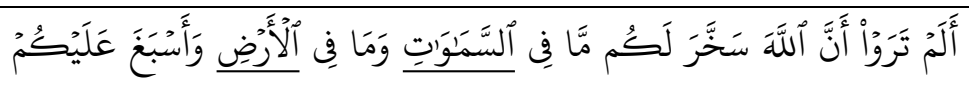 & Binary antonymy \\
\hline
\end{tabular}

\footnotetext{
1 Raffy, "Muahammad Ali al-Khuly" dalam http://raffy.ws/author/4352/\%D9\%85\%D8\%AD\%D9\%85\%D8\%AF\%D8\%B9\%D9\%84\%D9\%8A-\%D8\%A7\%D9\%84\%D8\%AE\%D9\%88\%D9\%84\%D9\%8A diakses 21-September2017
} 


\begin{tabular}{|c|c|c|c|}
\hline & & 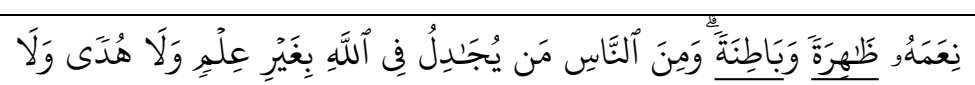 & \\
\hline 6 & 25 & 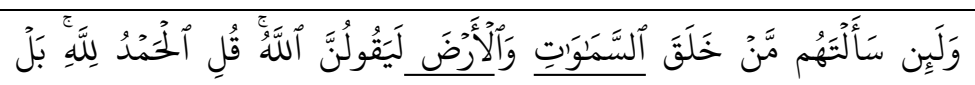 & Binary antonymy \\
\hline 7 & 26 & 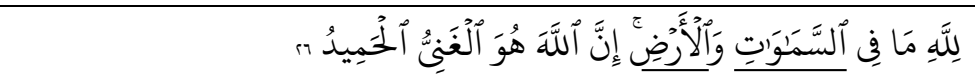 & Binary antonymy \\
\hline 8 & 27 & 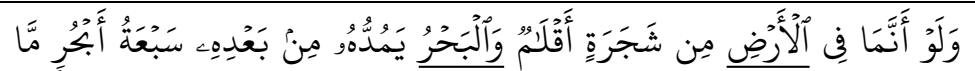 & Antonim bagian \\
\hline 9 & 29 & 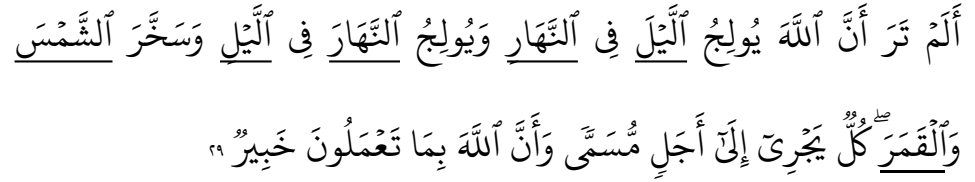 & $\begin{array}{l}\text { Cycling antonymy } \\
\text { dan affinity }\end{array}$ \\
\hline 10 & 33 & 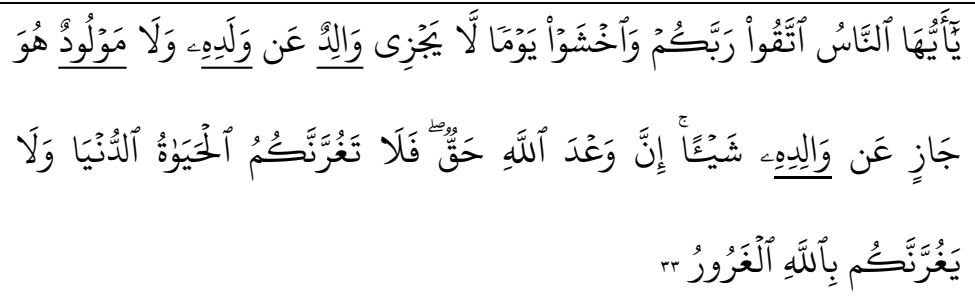 & $\begin{array}{l}\text { Conversense } \\
\text { antonymy }\end{array}$ \\
\hline
\end{tabular}

Dalam ayat 10 terdapat antonim yakni pada kata السماوات (langit) dan الارض (bumi). Kata ini merupakan antonim jenis تضاد حاد / binary antonymy atau antonim mutlak jika ada langit pasti ada bumi. Dan kata ini tidak merupakan antonim bertingkat karena tidak mungkin ada kata sangat langit atau kurang langit. Dan kata ini juga tidak masuk dalam kategori antonim bagian karena langit bukan bagian dari bumi. Dalam kata langit Allah menggunakan jamak سماوات dari kata tunggal Sedangkan al-Qur'an menggunakan bentuk tunggal dalam kata bumi yakni ارض yang berarti satu bumi. 
Pada ayat 12 terdapat kata yang berantonim yakni pada kata يشكر (bersyukur) dan كفر (kufur). Kata ini merupakan antonim jenis تضاد حاد / binary antonymy, karena kufur lawan katanya hanya syukur. Tidak seperti pada ayat 10 yang secara morfologi mempunyai kesamaan seperti dua kata tersebut menggunakan al-ta'rif dan dua kata tersebut adalah kalimat isim. Sedangkan pada ayat ini kata syukur menggunakan bentuk fiil mudhari' sedangkan kata kufur menggunakan kata kerja bentuk lampau atau fiil madhi.

Ayat 16 dalam surat Luqman terdapat kata yang berantonim yakni kata ارض dan dماوات Sekalai lagi langit dengan bentuk jamak dan bumi dengan bentuk tunggal. Kata langit dan bumi dalam ayat ini adalah sebuah pengibaratan ketika Luqman memberi nasehat pada anaknya. Nasihat itu berisi informasi bahwa Allah akan membalas perbuatan manusia walaupun seberat sawi dan walaupun berada dalam batu yang berada di bumi ataupun dilangit niscaya Allah akan membalas amal tersebut.

Dalam ayat 17 terdapat antonim yakni pada kata أمر (memerintah), dan غي (mencegah), selain pada kata معروف (kebaikan) dan منكر (kemungkaran). Kata امر dan في sama-sama menggunakan bentuk kata perintah (fiil amr). Kata ini menggunakan antonim berjenis biner تضاد حاد, hal ini di karenakan lawan kata dari kedua kata ini bersifat mutlak dan tidak bersifat gradasi. Sedangkan antonim berikutnya adalah kata معروف dan منكر karena dua kata ini berupa ajektifa atau kata sifat maka, dua kata masuk pada kategori antonim bertingkat atau di sebut graded antonymy.

Kata antonim berikutnya yakni pada ayat 20 pada lafadz باطنة - ظاهرة , dan - سماوات . kata dan ارض derulang lagi pada ayat dua puluh akan tetapi berbeda dengan ayat 16, dalam ayat 16 bumi dan langit menjadi pengibaratan, akan tetapi pada ayat 20 berisi informasi bahwa Allah telah memberikan karunia berupa bumi dan langit agar selalu di manfaatkan oleh manusia. antonim berikutnya adalah pada kata ظاهر (yang terlihat) - باطن (yang bersifat bathin "tidak terlihat") dua kata merupakan antonim jenis biner kata lawan katanya mutlak. Pada 
ayat ini menujukkan bahwa Allah telah menundukkan langit dan bumi untuk menusia tidak hanya itu Allah juga menyempurnakan kenikmatan manusia dengan kenikmatan yang bersifat dzahir dan bathin.

Pada ayat 25 dan 26 juga membicarakan tentang langit dan bumi. Kata langit dan bumi pada ayat 25 menjadi objek pertanyaan, yaitu dengan pertanyaan "Siapakah yang menciptakan langit dan bumi?". Berbeda dengan ayat sebelumnya pada ayat 26 kata langit dan bumi menjadi kepemilikan, bahwa bumi dan langit sama-sama milik Allah dan Allah adalah dzat yang kaya dan terpuji.

Dalam ayat 27 terdapat antonim berjenis juziy atau bagian yakni pada kata ارض (bumi) (laut). Antonim masuk pada kategori juziy karena laut merupakan bagian dari bumi. Dalam quran terjemahan Kemenag juga teredapat antonim lagi yakni pada kata قالام (pena-pena) akan tetapi al-Qiran tidak menyebut antonimnya yakni tinta (حبر), sedangkan dalam terjemahannya terdapat kata tinta. Antara حبر-قلم juga merupakan antonim berjenis juziy karena tinta merupakan bagian dari pena. Ayat ini menejelaskan bahwa Allah ilmu itu tidak terbatas dengan mengibaratkan jika seluruh pohon di dunia ini dijadikan pena dan seluruh air laut dijadikan tinta dan di tambahkan tujuh laut lagi niscaya ilmu Allah tidak akan habis.

Pada ayat 29 al-Qur'an menggunakan antonim jenis putaran atau cycling antonymy, yakni pada kata ليل(malam)- فار (siang), dan al-Qur'an membalik redaksinya dengan kata ليل-هار. Siang dan malam termasuk antonim jenis cycling karena siang dan malam merupakan perputaran hari. Sedangkan pada antonim kata شمس (matahari) dan قمر (bulan) termasuk kategori jenis affinity antonymy. Hal ini dikeranakan antara matahari dan bulan berasal dari jenis yang sama yakni jenis benda langit. Pada ayat ini terdapat pesan bahwa Allahlah yang mengatur pergantian siang dan malam dan Allah pulalah yang mengatur peredaran bulan dan matahari hingga keduany mampu berputar pada porosnya.

Sedangkan pada ayat ke 33 al-Qur'an cenderung menggunkan antonim jenis conversense/تضاج عكس. Hal ini dapat kita lihat terdapa 4 kata yang berantonim yakni pada 
kata والد (orang tua) - ولد (anak laki-laki), مولد (orang yang dilahirkan 'anak') - والد (orang tua).

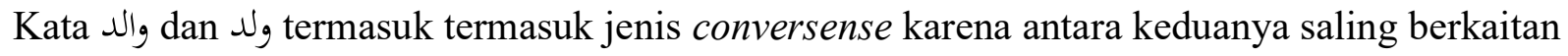
dan tidak dapat dipisah, ketika bicara tentang orang tua pasti ada anak. Begitu juga pada kata dan juga tidak dapat dipisahkan, karena mustahil jika ada orang dilahirkan tapi tidak ada orang yang melahirkan. Oleh sebab itu seluruh kata dalam ayat ini seluruhnya menggunakan antonim jenis kutub / conversense. Ayat 33 ini berisi berita tentang hari kiamat pada hari kiamat, pada hair kiamat seorang bapak tidak bisa menolong anaknya. Dan begitu juga sebaliknya, seorang anak tidak dapat pula menolong orang tuanya.

Dari hasil analisis menunjukkan bahwa tidak seluruh ayat al-Qur'an dalam surat Luqman terdapat kata yang berantonim akan tetapi hanya 10 ayat yang terdapat kata yang berantonim. Jika dilihat dari jenisnya menurut prespektif Muhammad Ali al-Khuli terdapat sembilan jenis antonim akan tetapi tidak semua ayat dalam surat ini mencakup kesembilan jenis ini. Biner, bagian, cycling, conversense, graded, dan affinity. Dan kata antonim yang paling sering muncul adalah pada kata سماوات dan ارض

\section{F. Simpulan}

Surat Luqman termasuk ketegori surat Makiyah dan secara urutan surat makiyah adalah surat ke-31 dalam Mushaf Utsmani. Jumlah ayat dalam surat Luqman adalah 34 ayat. Dalam Surat Luqman terdapat beberapa ayat yang di dalamnya terdapat kata yang berantonim. Dari 34 ayat terdapat 10 ayat yang di dalamnya terdapat antonim yakni pada ayat 10, 12, 16, 17, 20, 25, 26, 27,29, dan 33. Muhammad Ali al-Khuli mengkategorikan jenis antonim menjadi sembilan. Akan tetapi tidak semua dari kesembilan jenis ini terdapat dalam surat Luqman. Terdapat enam jenis antara lain: Biner, bagian, cycling, conversense, graded, dan affinity. 


\section{Daftar Isi}

Muhammad Iqbal A. Gazali. 2010, Fadhlu Qira'at Al-Qur'an. Mamlakah Saudi: IslamHouse.

M. Quraish Shihab, et. all.2008, Sejarah dan Ulum Al-Qur'an, Jakarta: Pusataka Firdaus

Chaer, Abdul. 1989, Penggunaan Imbuhan Bahasa Indonesia. Flores: Nusa Indah.

Abdul Chaer, 2002. Pengantar semantik bahasa Indonesia. Jakarta : Rineka Cipta.

Harimurti Kridalaksana, 2001. Kamus Linguistik. Jakarta: Gramedia Pustaka Utama.

Mohammad Matsna, 2016, Kajian Semantik Arab Klasik Dan Kontemporer, Jakarta: Kencana.

Mohammad Kholison. 2016, Semantik Bahasa Arab Tinjauan Historis, Teoritik Dan Aplikatif,

Sidoarjo: Lisan Arabi.

Harimurti Kridalaksana, 2001. Kamus Linguistik. Jakarta: Gramedia Pustaka Utama.

Soedjitno. 1990. Kosakata Bahasa Indonesia. Jakarta: Gramedia 